\title{
THE 'FRENCH BITTERNESS': POPULISM AND MOBILIZATION IN THE LIGHT OF GLOBAL UPHEAVALS AND NEW CLEAVAGES
}

\author{
Roberto de Rosa ${ }^{1}$ and Niccoló Inches ${ }^{1 *}$
}

${ }^{1}$ University Niccoló Cusano, Rome, Italy

* Correspondent author: Niccoló Inches - niccolo.inches@ unicusano.it

Received: 3.12.2020; Accepted: 16.12.2020; Published: 20.12.2020

DOI: https://doi.org/10.46473/WCSAJ27240606/20-12-2020-0023

Category: Research paper

\begin{abstract}
In recent years, the debate on populism and how it is affecting liberal democracy has become a central point of political debate. France particularly represents an interesting case study for the presence of political forces attributable to this area. On the one hand, the country contends with the Front National political party, which has proudly called itself "national-populist" since 1978, and, on the other, a new protest movement, which, however, also uses an antagonistic and anti-elitist approach exists.

The former has undergone a long evolution over the years while the latter has just been born in a "spontaneous and self-organized" form. Nevertheless, both seem to be located within a new "center-periphery" cleavage.

Parties' and voters' reorganization follow new conflicts and, particularly, the great divide between 'winners' and 'losers' of global phenomena. Such an opposition synthesizes the consequences of inequalities among members of the same national community. The ideal configuration of internal boundaries within a national society, as Ernesto Laclau claims, is logically assimilated to the cleavage between the 'People' and the 'Establishment', which is the core of the current populist storytelling.

This article aims to highlight the manifestations of the populist phenomenon in the French context with the analysis of these two collective actors and how they are placed in the context of new social and political fractures in which a huge part of the social body has experienced political radicalization triggered by social changes and amplified by upheavals in the world's economy or migratory and terrorist crises between 2008 and 2016.
\end{abstract}

Keywords: Populism, France, Front National, Yellow Vests 


\section{Introduction}

In the period straddling the last two decades, the debate on the characteristics of populism has appeared as a specific issue concerning liberal democracy, as long as it is perceived as the display of social and cultural crisis affecting several countries across Western Europe and North America, what Cas Mudde called a "pathological normality" (Mudde, 2017).

Contemporary processes like European integration and globalization - and their effects in terms of 'de-nationalisation' of public policy - have accelerated a tangible recomposition within Western political systems. Parties' and voters' reorganization follows new conflicts and, particularly, the great divide between 'winners' and 'losers' of global phenomena. Such an opposition synthesizes the consequences in terms of inequalities among members of the same national community (Kriesi et al., 2008, 4ff.). The ideal configuration of internal boundaries within a national society, as Ernesto Laclau claims, is logically assimilated to the cleavage between the 'People' and the 'Establishment', which is the core of the current populist storytelling. This dichotomy is the core of a fundamental Weltanschauung expressed by populist actors, in the framework of a Manichean rhetorical vision of politics which separates the 'Good' and the 'Evil' (Hawkins et al., 2018).

In illustrating a socio-cultural approach to the analysis of populism, Pierre Ostiguy highlighted the "high-low" opposition as a paradigm of the deep divide between the élite and the rest of the social body (Ostiguy, 2017, 73). This dimension of analysis is crucial in conceptualizing the populist phenomenon, to avoid trivializations that can reduce it to a simple dynamic of mass manipulation. In this sense, Ostiguy relies on the expression "flaunting the low" in order to designate the celebration of good and simple people, representing a cultural construction that precedes politics. Consequently, populist actors who emphasize the importance of being 'close to the people' make a distinction in politics between a 'high' and a 'low' dimension and adjust their own public discourse according to it. This explains the particular use of unwritten propaganda codes and rules: whereas 'high' politics corresponds to a political style where a moderate and impersonal authority coexists with a procedural vision of democratic processes and a cosmopolitan approach, 'low' politics, on which populist actors intend to legitimate their advocacy, is imbued with a low-level mediation between representatives and voters, which is expressed by a personalistic leadership style using a simple-minded and exclusive discourse. In this regard, the main element that populist actors have in common is the appel au peuple, which is considered in its indefinite whole except for the élite members.

Beyond the populist spread within the European democracies in the last twenty years, Dominique Reynié underlined how the common trademark of several cases of this phenomenon remains the reference to a "mythical, ideal or imaginary" people (Reynié, 2013, 25 ), in which there are no differences in terms of classes but a radical dichotomy between a 'corrupted élite' and the 'pure people'. In this sense, Populism is a conception of politics foreseeing a polarization between the 'establishment' and a homogeneous people supposed to be the only entity embodying these pure values. In fact, only the latter can represent the whole that we call 'the Nation'; ideally, the People that populists evoke are placed at the core of a 'vertical' political cleavage in which it is opposed to highest categories and the ruling class, which must be morally separated from the rest of the society.

The main question, obviously, is how does spreading populist phenomena affect liberal democracy? France, in particular, represents an interesting case study for the presence of 
political forces attributable to this area. So, this work aims to outline the dimensions in this very specific framework and answer the question: How does this phenomenon manifest itself in the context of French politics? Beyond the populist contagion (Rooduijn et al., 2012,; Mudde, 2004) which has made the populist discursive style also typical of mainstream parties, for a correct analysis of the phenomenon it seems appropriate, in the French case study, to dwell mostly on two actors who, in a more evident way, embody the subtle populist ideology (Mudde but also Freeden) in this reality: on the one hand a party that proudly calls itself "National-populist" since 1978 (Taguieff, 1984) the Front National, and on the other a new protest movement, which however also uses an antagonistic and anti-elitist approach.

A first hypothesis is based on the idea that the renewed political momentum of the FN (now Ressemblement National) and the broad consensus that gathers the GJs' movement is due to the rediscovery of a new kind of "center-periphery" cleavage.

Parties' and voters' reorganization follows new conflicts and particularly the great divide between 'winners' and 'losers' of global phenomena; such an opposition synthesizes the consequences in terms of inequalities among members of the same national community (Kriesi et al., 2008).

Finally, in support of the first hypothesis, we must consider the possible growing polarization and radicalization that is once again characterizing the political field. Peter Mair (2009; see also Katz and Mair, 1995) illustrated a growing tendency of democracies to de-polarize and de-politicize, which has seen the political elites of Europe reshape themselves into a homogeneous professional class, withdrawing into state institutions, but precisely because of the self-referentiality of the political class in times of global economic crisis, the antagonistic approach (Panizza, 2005; Laclau, 2008) becomes a stimulus for new polarizations not marked by political partisanship.

The ideal configuration of internal boundaries within a national society, as Ernesto Laclau claims, is logically assimilated to the cleavage between the 'People' and the 'Establishment', which is the core of the current populist storytelling

As explained by Panizza $(2005,3)$, antagonism is thus a mode of identification in which the relation between its form (the people as signifier) and its content (the people as signified) is given by the very process of naming.

Populism is, therefore, an anti-status-quo discourse: it is part of a struggle over hegemony and power. A struggle in which the FN and the GJs are leading actors in current-day France.

\section{France through the Looking-Glass: populism and new cleavages between reality and perception}

For several years, French society has undoubtedly known a widespread feeling of political distrust. Such a climate is followed by a picture of multiple inequalities, in which resentment, discontent and fear of social downgrading result in a sort of individual perception rather than a holistic analysis. The growth of some riot phenomena like the one of the "Yellow Vests" as well as the rise of radical parties within the political system seem to be a physiological effect of double anxiety that has been exacerbated by Globalization. On the one hand, social insecurity due to the economic context and lack of employment, particularly with respect to low-specialization professional fields; on the other hand, cultural insecurity due to the 
perceived upheaval of national and international order. The latter appears as an "individual and collective representation" leading to distrust towards diversity and multiculturalism:

"La différenciation des territoires et des populations (...) ainsi que les 'fractures' qui les séparent de plus en plus nettement, notamment en raison des effets de la mondialisation, jouent un rôle considérable dans la formation des appréhension et des attitudes" (Viard, 2011, 87).

Its most prominent manifestation is the development of a significant consensus for the national-populist right (Taguieff, 2012), standing as the main political 'entrepreneurship machine' in intercepting resentment or pessimistic attitudes in the heart of French society. Thanasak Jenmana and Amory Gethin underlined how the growth of actors placed on the 'extremes' sides of French political landscape, like the National Front, can represent the symptom of a deep individual dissatisfaction which is linked to well-being and confidence in the future. Actually, political polarization is a process that has seen no pause since the beginning of the 2000s, in parallel with the slow decline of traditional party representation that experienced its highest on the occasion of 2017 presidential elections (Jenmana and Gethin, 2017). In particular, Simon Bornschier (2019) identified European integration as a major issue in restructuring the French political framework and cleavages between the 1980s and 1990s. This joined and implemented the debate on migratory flows and multiculturalism within public opinion, as well as the one upon deregulating the national economy, which has been dealing with the doctrine of Etat stratège - strategic public intervention - for a long time.

Post-ideological cleavages have implemented the polarization of French political landscape, by leaving the typical "horizontal" dimension of social classes and embracing a "vertical" one, which is expressed both on a cultural level - 'cosmopolitan' citizens vs French 'natives' - and on a governance level in which global openness is opposed to protectionism. Against the backdrop of a society that knows a solid secularisation, where party competition used to take roots on religious cleavage - Socialist/Communists vs Catholics (Le Bras and Todd, 2013) the scheme of current political conflict seems to shift to the dual dimension between economy and identity, within which the latter often prevails. Therefore, a divide seems to emerge between those citizens embodying liberal values and citizens who plead an "exclusive conception of the community".

On the other hand, the economic dimension and, specifically, the issue of public sector management (in the light of financial duties and bonds vis-à-vis the European institutions) became a crucial issue of protest for both populist right and the radical left, on the frontline among the convinced supporters of the 'Nay' to the referendum on the Maastricht Treaty (1992) and the Draft of a Constitution for European Union (2005). These polls, which sought to deepen the EU integration, have crystallized a general climate of political disaffection, but above all, have set the cornerstone of the "people VS elite" storytelling which has progressively reached its highest in the last decade. In this sense, the arguments for the "Nay" to the project for a European Constitution in 2005 allowed for the federation of several groups affected by such social anxiety, which in turn, established itself as an undisputed part of the Eurosceptic stream across the European continent (Sauger, Brouard and Grossman, 2007). 
WORLD COMPLEXITY SCIENCE ACADEMY JOURNAL| Vol. 1 Issue 3,14 | Winter 2020

\section{National Front's ideological shift}

Historical and political events referring to the Front/Rassemblement National legacy seem to suggest a capability developed by the main European national-populist right party to embody such configurations. As its positioning on the right-left axis is the result of historical economic and social fractures, positioning on a cultural dimension must be added as long as it toggles between an opportunistic openness in terms of rights and civil liberties (known as "post-materialist" ones) and the traditional defense of conservative and hierarchical values (authoritarianism). From this point of view, its ethnonationalism contributes in placing the $\mathrm{NF} / \mathrm{RN}$ on the extreme right of the political scheme (despite the refusal by its members to be given such label), giving priority to a post-ideological identity ("ni de droit, ni de gauche") which has particularly marked the most recent political debates. It is relevant to observe that the FN/RN can be ranked as a populist actor by virtue of the discursive style shown by its founder Jean-Marie Le Pen, who has undeniably embodied a model of patriarchal and personalistic leadership.

Between the first rise of the party (1984 European elections) and the peak of consensus achieved by Jean-Marie Le Pen's daughter, Marine, from 2012 to 2017, what explains its growing attractiveness is the coexistence between 'exogenous' issues (the economic, cultural, political crisis) and endogenous ones, like the struggles against crime and insecurity and its impact on the social perception of migrants. Whereas, in the 1980s and 1990s, the Lepenist narrative outlined a link between foreigners and criminality in the heart of French cities, as well as an aspect of a supposed "patrimonial" threat (migratory flows involve individuals who feed a low-cost workforce), Marine Le Pen's NF, has been dealing with this issue by deepening an identitarian perspective. Thus, opening national borders would mean a rise of criminality figures but also encouraging the dilution of native cultures and national values' upset. In explaining such an attitude, Yascha Mounk (2018) mentioned the 'demographic anxiety' characterizing Western radical rights: the idea that those who are part of a majority community could soon become members of a new minority, as a result of the unstoppable growth of migrations, especially from Arab and African countries, carrying cultural transformations.

Otherwise, once Marine Le Pen secured party leadership in 2011, NF embarked on an ideological renewal, even though it has never denied values from 'old-school' Lepenism. Since the mid-1990s, there had already been a new melt between an ethnocentric cultural perspective and a state-centered vision from the point of view of socio-economic policies (Gombin, 2016). Whereas former leader Jean-Marie Le Pen already marked a turning point by introducing a 'social' dimension into the FN's propaganda on the occasion of the 1995 presidential election, by giving up previous free-market and Reagan-inspired programs (Dézé, 2016), Marine Le Pen exacerbated such a commitment on Welfare policies (Perrineau, 2014) to support the economic demand and public services, in parallel with a consolidation of security and law-enforcement functions. At the same time, she assumed the so-called 'national preference' clause; in other words, the leader set a hierarchical ranking for allocating public subsidies by giving priority to French citizens or natives. Overall, public activities that are supposed to grant general interest, such as policies of aménagement territorial (for giving equality of chances among internal regions, infrastructure and buildings, or State holdings in strategic sectors) stand as a national asset to be defended as long as they have been 
squandered for decades by neoliberal policies, which have been supported by both centreright and socialist governments (Espagno and François, 2015).

In the past, NF's discourse focused on the wastage of public resources or the minimization of the relevance of the 'State issue' in its political programs. Now, however, protecting the local and territorial services has become an issue that signifies the ideological shift from the National Front's initial experience; at that time, the anti-communist struggle was the main aspect shared by all the extreme right-wing actors in Europe. In this sense, in the beginning, the NF promoted a synergy between economic liberalism and cultural conservatism, oriented towards the valorization of private initiative and autonomous professional categories, by appealing to a state-phobic style. 'Old-school' NF fostered hostility towards public administration in the same way that anti-fiscal discourse was promoted by the previous populist experience known as Poujadisme (1953-58) .

Nowadays, a similar discourse that uses anti-system criticism has been implemented with respect to the traditional party system and the so-called European Union technocracy (Perrineau, 2014). The complaint vis-à-vis the deepening of European integration is exemplified by a reluctance to return to old national currencies and a refusal to relax immigration policies at borders set by the Treaty of Schengen, and are part of more general opposition to the economic and cultural effects of Globalization, which is considered by populists to be the main source of French decline (Dézé, 2016). This logic is consistent with the double cleavage 'globalism vs anti-globalism' and 'Multiculturalism vs Nativism' (Mudde, 2017) debate that has marked other populist phenomena across Europe, signifying a moral polarization (Müller, 2016).

Dominique Reynié (2013) coined the expression 'Patrimonial Populism' which could be defined as a political stance that aims to appease a twofold concern within the social body, both in economic terms - as long as it implies the protection of a traditional welfare model and protectionist policies in the field of international trade regulation - and in terms of cultural security. This strategy has been defined by Reynié himself (2011) as "socialpopulism" or "ethno-socialism", as it describes the will to preserve a genuine way of life and cultural horizon, which help to feed a national sense of belonging against the backdrop of a "threat" of global flows, as long as they bring new identity settlements and cleavages.

In the electoral campaign of May 2014, especially, the typical triad of "unemployment, immigration, insecurity" declined with the theme of French "decadence" and Euro-skeptical issues became an undoubted success. When considering the fact that young people (18-35 years) are the ones who are most affected by the economic crisis, then the themes and instruments used are particularly suitable to the need (Crépon, 2012; Battaglia, 2017).

The "Decadence de la France" theme (Orfali, 2012, 58) is a coherent concept in the basin of the French extreme right; it always stems from an ideological point of view and tends to push citizen participation. The decadence, both material and ideological, does touch France, of course for the activists of FN, in an obvious manner and the vote for the FN and Marine Le Pen is a way of redresser la France (a slogan already used during presidential elections in 2012), which was used as the background by the latest EPE: "Raise France" which is meant to convey the restoration of a strong national State that is capable of protecting those forgotten by European policies. 
Younger generations are then confronted with an image of a lost paradise that can be regained, the aim of which is attractive. Nevertheless, the setting in which they act is fraught with danger and enemies and is characterized by a few distinctive elements including a lack of confidence in institutions, a complaint of democratic deficit, distrust towards the elites in power, increasing youth cynicism, increasing tendencies to being unpolitical, a rejection of hierarchies, the hope of a democratic renewal thanks to Web 2.0, criticism of the role of the media (complaint of partiality), and the valorization of activism.

It is within this new framework of "normalization" that the narration takes place, making typical the issues of the FN force elements which try to emphasize the role of a new antisystem "Hero".

In interpreting its anti-system vocation, Marine Le Pen's NF chose to show its political advocacy by setting a moral distinction between a 'de-spatialized' establishment and the lower-middle classes who are mainly located in the suburbs and post-industrial areas (Ivaldi, 2015). NF's leader turned immediately to a France of invisible people, belonging to a rurban or peri-urban social class (Wieviorka, 2013), which is composed of workers, farmers, craftsmen and victims of unemployment. Compared to the usual adage on the 'deep France' (identifying old-style rural province), the "people below" (Guilluy, 2016) are generally identified as the victims of global processes who have also been forgotten by mainstream media and politics.

The 'bogeyman' of globalism and multiculturalism is evoked hand-in-hand with the effects of new financial and austerity policies implemented by European institutions. Phenomena or practices like productive relocation and employment dumping gave rise to a popular backlash which has unveiled a new form of nationalism incorporating the defense of economic sovereignty and social protection for 'excluded' natives (Slama, 2016). In this sense, it nourished the theory about a so-called "leftist lepenism": while in the past workers were 'deterministically' assigned to the left's advocacy, nowadays they seem to shift to the right and especially to the NF (Gougou, 2015). Thus, Marine Le Pen's will to set bondage with working-class is evidence of a fundamental shift made by French populist right since the last 1990s, while the very first rise of the extreme right simply reflected the urban upper classes' discontent and radicalization vis-à-vis François Mitterrand's power in the 1980s (Gombin, 2016). From this point of view, since her first candidacy for the 2012 Presidential elections, Marine Le Pen has contributed to implementing the dynamics of 'electoral realignment'.

Over time, working classes have been characterized by a general disaffection for political participation (Huelin, 2013) especially regarding Communism and leftist parties overall. This occurred in parallel with the progressive collapse of working-class cohesion and unity, which used to be associated with a strong collective awareness granting a high rate of participation at trade unions. Class homogeneity has been replaced by inequalities between skilled workers, who have gradually afforded middle-class standards, especially in terms of housing choices (leaving old collective housing in the suburbs, known as the HLM , and choosing independent houses in the periurban area) and high-level profiles from the tertiary sector (Wieviorka 2013). The fall of the Soviet Union the resultant ideological crisis led to the electoral downsizing of the French Communist Party and to a sort of unionism 'slowdown'. Apart from the rise of electoral abstention, a political alternative for workers became the poll in favor of the NF. Marine Le Pen's party is taking advantage of a higher consensus among workers, 
which is even bigger than the one in favor of the PCF at the turn of the 1960s and 1970s when the Left gathered up to $70 \%$ of the working-class vote (Huelin, 2013). Despite the quantitative decrease of the workforce and the lack of a real Lepenist "counter-corporation", comparable to trade unions and to the system of power granted by communists in councils and local administrations between the 1950s and 1970s (Communisme municipal), it is quite undeniable that NF realized a breakthrough within the working-class. The connection between internal fragmentation and functional divide within the working class has favored workers' endorsement of the NF, in particular among specific profiles like drivers and hauliers, which are traditionally not unionized (Fourquet, 2017). Moreover, because of the growth of professional shapes known as "service" workers employed in warehouses and small industries far from city centers, the working class is growing less socially visible (Huelin, 2013). Nevertheless, such a right-wing shift among workers appears to be the result of a loss of ideological references rather than a convinced adhesion to the populist right's system of values (Michelat and Simon, 2012). In this sense, it stands both as a protest stance as well as a demand for economic protection with respect to contemporary challenges.

\section{New Kids on the Block: The Gilets Jaunes as a territorial dimension of discontent}

The Gilets Jaunes (Yellow Vests) label identifies a "spontaneous and self-organized" (Lévy et Lussault, 2019, 26) movement developed without any support from trade unions or parties, being highly compound and crossed by contradictory factions (Marlière, 2019). When looking for common elements with French political populism, some authors noticed how YV's discourse initially fed on anti-fiscalism, a typical trait of Poujadisme, launched by Pierre Poujade in order to offer advocacy and social protection to small entrepreneurs threatened by tax burden and capitalist innovations (Fourquet, 2018).

Since the very first mobilizations in November 2018, demonstrators have provoked traffic stops in multiple locations on French territory. Their initiatives have been qualified by some observers as a contemporary form of Jacquerie or, in any case, an example of local riots which have progressively taken on a national dimension (Boyeret al. 2019). In the light of a long tradition in France, scholars saw in this mobilization the overwhelming return of a 'revolutionary' echo which, thus far, was thought to have been asleep after the collapse of the Soviet world and the hegemony of political and economic liberalism, which seemed to have archived this way of political change definitively (Mazeau, 2019). Nevertheless, the territorial dimension of the 2019 protests introduced a relevant difference with respect to former historical episodes of riot in France, from a social and geographical point of view. There are a few points in common with 1789 events; while the French Revolution was animated by artisans and small urban traders who were oppressed by the privileges of clergy and aristocracy, the Yellow Vests' movement emanates from the peripheral territories and belongs to an era in which civil liberties are guaranteed, standing as a claim for fairness and fiscal justice . At the same time, the movement differs from the one of May 1968, which emanated from a protest in the heart of Paris and later spread to the working class of the surrounding urban sectors. Referring to this aspect, YV are characterized by an inverse dynamic as they appear "no longer as the result of contrasts produced by centrality, but rather as the consequence of a logic of social separation that affects urban spaces in the light of the same extension of those spaces, the effect of increased mobility" (Donzelot, 2019, 36).

The 'mobility issue' is crucial in explaining YVs' spread, insofar as the first wave of demonstrations met social rage towards an escalation of burdens in terms of economic 
circumstances (rising oil prices) and governmental measures. Among these, there is not only the last fuel tax increase but also the traffic restrictions for diesel engines, the increase in roadworthiness testing and motorway tolls, as well as the lowering of speed limits on secondary roads from 90 to 80 kilometers per hour (Fourquet, 2019). The YV protest is part of a general context of strong perceptions of inequalities and failings in social policies, which have fostered a widespread climate of distrust towards liberalism in modern Western democracies. In fact, there is an overlap between protesters and representatives of a middle class composed of the so-called 'invisible' individuals, who are misunderstood or even despised by the ruling classes and affected by a sense of precariousness despite the ownership of a professional position (Gomant 2019). Serge Paugam notes that the demonstrators stand out for their "fragile integration" within social and economic circuits: "Overall, they are not characterised by the lack of employment. Otherwise, they work and yet do not feel recognised" (2019, 39). A 2018 IFOP-Foundation Jean Jaurès inquiry highlighted a percentage of identification with the GJ initiative of $18 \%$, also stressing the 'modest' nature of the supporters of the 'roundabout mobilisation': between $23 \%$ and $31 \%$ of YV sympathizers declared that they belong to the categories of workers, craftsmen and small self-employed workers; $29 \%$ of participants also stressed the precarious nature of their profession. From this point of view, Jerome Fourquet isolates two categories within the group: the so-called caristes, workers in charge of logistics at large distribution warehouses, and care professionals; in both cases, these represent 'service' professions that are poorly remunerated and requiring a low qualification .

At the very beginning, the protest unfolded on both the roundabouts of the 'rural peri-urban' and the 'metropolitan peri-urban'. The Yellow Vests come mainly from territories outside the perimeter of large cities: the cartography of gathering points shows a low presence in large agglomerations and metropolitan centers (Lévy, 2013). From this point of view, the roundabout which became the symbolic place for YV is not merely a typical landscape element of French territory anymore but stands as the crucial spot of mobilizations with respect to its role for traffic decongestion. By this kind of mobilization, the YV movement aims to offer visibility to social groups who are located in areas suffering from the burden of mobility more than others. In this sense, the movement is practically missing around the main hubs of public transport networks, such as airports and railway stations (Depraz, 2019).

Therefore, the movement stands as a showcase for the claims by people living far from the ville-centre (Bruneau, Mischi and Renahy, 2019), in which the category of white-collar workers is overrepresented. Similarly, the Yellow Vests "live in the widespread peri-urban area" which hosts an increasing population, a multitude of "small micro-located peoples" around the "occupied roundabouts" (Lussault, 2019, 173-174). The peri-urban condition evoked by the geographer Michel Lussault (2012) is not necessarily characterized by a greater marginality, a condition that exists within the bigger cities' area mainly (Lévy, 2013). Samuel Depraz (2019) shares this interpretation when he claims that 'peri-urban France' includes social sectors being less affected by unemployment and can afford ownership in real estate. Therefore, protesters and categories defended by the YV are not excluded from the consumer circuits. The litmus test of the peri-urbanization process, in other words, a tangible sign of the changes in French society during last decades is the possibility for families to realize their aspiration with regards to housing properties; this circumstance is almost unthinkable within the area of big cities like Paris, due to the higher costs. Access to estate property is a guarantee for capital transmission within the same legacy, a hope of social progress for the 
following generations (Lussault, 2019). Dynamics of settlement in the peri-urban area, as claimed by Depraz (2019), is an example of the "urbanism of opportunity" which has been introduced as a vector for social promotion, even though it can be seen as an opportunity to escape from the deep precariousness of the suburbs.

Pierre Veltz (2019) identified a primary source of YV mobilization in new territorial cleavages, as long as the spatial distance between home and workplace has 'significantly increased' for growing groups, as a result of the concentration of professional activities in big cities and the dispersion of house settlement. Veltz stresses, once again, a "very widespread and fragmented process of periurbanisation", particularly referring to the "suburban layers surrounding large cities, where population and services are extremely atomised". Consistent with this reasoning, Samuel Depraz argues that the YV protest came out from the peri-urban areas' dependence on large conurbations, in terms of employment and services, which made the increasing fuel costs so unacceptable (2019). In addition, the peri-urban areas are related to the so-called "obligatory expenses" in which these ones have peremptorily concentrated: a set of routine charges like estate loans, insurances and subscriptions to services. Apart from the housing settlement strategies, such a phenomenon often shows a high level of car ownership for almost every family. Since the source of the protest can be found in areas corresponding to the 'peri-urban crowns', with respect to metropolitan cores, an overlap between YV members or sympathizers and the so-called navetteurs can be unveiled, as long as those citizens have known a lengthening of the journey from home to the workplace.

As around one-third of the active population does not work in the same territory of residence, the increasing share of navette is effectively due to the spatial gap between economic cores and living spaces. At the same time, employment has progressively concentrated within the most dynamic cities (Métropoles) like Paris, Lyon, Marseille, Toulouse, Rennes, Nantes, Bordeaux (Reynard and Vallès, 2019). Thus, despite its heterogeneity, the YV mobilization shares a specific aspect: the dependence on the car, which is seen as an indispensable means of mobility pertaining to the needs of the population involved. Particularly, this occurs out of urban circuits and public transport networks where the car almost represents a "second skin" for people who are involved (Le Bras, 2019). As Le Bras pointed out, unlike other goods of daily use or consumption, the costs of handling vehicles (including fuel, insurance, maintenance and tolls) are particularly heavy. From this point of view, the ecological tax increase would not only have had an impact on car-related expenses or items but on the whole family budget. Moreover, since de-industrialization brought the increase of unemployment rate and the reorganization of services at a local level in rural and peripheral areas, the car becoming an increasingly primal necessity, both for professional and educational needs (for ensuring children school attendance), healthcare displacements or simple supply needs (Bruneau, Mischi and Renahy, 2019).

Different social claims have emerged within the YVs protest: on the one hand, those by inhabitants of peri-urban areas who are not in poverty, but encounter various forms of precariousness, in terms of credit, taxation and the management of family affairs; on the other, those from citizens living in isolated areas crossed by the so-called Diagonale du vide, in other words, deep central territories suffering from a lack of investment and essential services (Le Bras, 2019). Thus, a linkage between the YV protest and a whole feeling that some authors called France triste ("Sad France") can be established (Perona, 2019). Social disease across the country is even more visible among groups on the border between the working and 
middle classes, in the light of levels of employment, income and education that have been emerging during recent times. From this point of view, the YV movement seems to configure a population "on the edge": the litmus test of a society which has been able to democratize access to higher education, but which has also allowed the development of stratified, autonomous and non-homogeneous schemes of analysis, especially among the youngest generations and the working class.

The YVs are a composite social body, coming mainly from territories that do not fall within the perimeter of biggest cities: the cartography of the collection points around the roundabouts denotes a low presence in the core of large agglomerations and metropolitan cores (Lévy, 2013), which inversely represent the places chosen for mobilization against power. Commenting on a survey which has been released before the outbreak of the YV, Mathieu Perona and Madeleine Péron (2018) underlined a greater propensity for social anxiety as well as a greater impact of the phenomenon known as the France malheureuse within urban areas of 20,000 and 100,000 inhabitants, an environment where there is a lower level of sociability and quality in relation to their family circle, peer groups and generally the local communities to which they belong.

In this sense, spatial characteristics about where the YV mobilization took root the most provide further indications of the origins of discontent. Several observers have underlined the correlation between the protest and social disease which is linked to the weakening socialization in the same areas. From this point of view, the mobilization is actually more intense within smaller urban units, where there has been a higher demographic decline (Algan, Malgouyres and Senik 2020). The concentration of economic activities in Métropoles (the main regional agglomeration with more than 200.000 inhabitants) launched a process of impoverishment of small-medium towns, dragging with it the progressive disappearance of public places and commercial services.

\section{Sense and Sensibility}

These two actors, briefly outlined in their distinctive characteristics, are both located in the depths of this new cleavage that characterizes Western society and France in particular. The first, with a long history behind it, has been able to sensibly transform and strategically adapt itself to the challenges of the time. The second was able to give voice to a new feeling thanks to a widespread sensibility in the social body that composes it. In any case, their struggle seems to comply with features of contemporary populism, as long as it expresses a wide sense of social decline. Hans-Georg Betz (1994) already emphasized the historical shift from an original interpretation of populism, in terms of emancipation and social progress (the supply of a credible alternative to capitalism or socialism), to a recent phenomenology of 'bad attitudes' in politics, such as anger and frustration, which are nourished by a perception of injustice. With respect to France, such a feeling has crept in through multiple trajectories, not only in relation to the individual or group condition but also vis-à-vis the perception of the country as an international, economic, political and cultural power, whose crisis can be glimpsed against the background of the shift of the centers of global wealth production (from the West to Asia), the difficult management of migratory flows and the security threat linked to terrorism (Giblin, 2017).

Incidentally, while a materialist prism dominated studies on political behavior after the 1950s (through the prism of class belonging), a cultural-oriented approach to electoral dynamics has 
prevailed since the 2000s; scholars have noticed how the inclination for populist vote goes beyond people's income level and material wealth .

La relation entre mal-être et vote frontiste s'explique principalement par la crise des aspirations. Après dix ans de croissance en berne, l'électorat du Front National est celui qui a perdu espoir dans son avenir et dans celui de ses enfants. Or, le pessimisme des Français se rattachant principalement aux perspectives économiques du pays (...) Le vote FN n'est plus celui des classes populaires, mais des classes malheureuses et pessimistes.

The post-ideological fracture lines that encourage the polarization of the French political landscape have, therefore, abandoned the 'horizontal' dimension, typical of the division into classes, embracing a 'vertical' one that is declined both on the socio-cultural level - between cosmopolitan individuals and a France of 'natives' - and from the point of view of economic governance, under the banner of the trade-off between liberalism and protectionism. David Goodhart (2019) pointed out that the YV season represents the dichotomy that the author himself coined between 'anywhere' and 'somewhere' groups: as the expression of social and economic frustration, the YVs belong to the latter, as long as they carry a rootedness and sense of attachment to a territory and a generic belonging to lower-middle social classes. They counter the first one, which is composed of individuals owning upper cultural capital who have benefited from the transition from industrial to the so-called "knowledge society".

The new centrality given to culture, within the analysis of contemporary forms of participation and electoral phenomena, is the issue of 'identity building' dynamics that may be seen as a claim inspired by the fear of the loss of social status. A huge part of the social body has experienced political radicalization, that has been triggered by social changes and amplified by upheavals in the world's financial, migratory and terrorist crises (2008-2016). Mistrust vis-à-vis so-called 'new rights' and cosmopolitan liberties has proved to be preparatory to the current growth of national-populist actors' consensus and for a spread of authoritarian values. Moreover, a generational divide has emerged between a declining Interwar generation and a Millennial generation that coexist in a general framework of electoral abstentionism and political disaffection (Norris and Inglehart, 2019). This has contributed to the analysis of the rise of anti-establishment phenomena, insofar as parties (NF) and movements (YV) aim to embody a declining vision of established social structures. The relevance that has been attributed to culture in analyzing these forms of political issues is likely to appear as a claim, moved by a sort of fear of losing both identity and social status.

\section{Conclusions}

As mentioned above, global processes are reshaping the political battleground, putting at stake the consolidated practices of representative democracy and giving space to new actors who, by strategy or style, fall into the analytical categories of populism. This is accelerating a noticeable modification within many Western political systems. In particular, it seems correct to point out how these phenomena define a new cleavage, between 'winners' and 'losers', that could be logically assimilated to the cleavage between the 'People' and the 'Establishment', which is the core of the current populist storytelling. A new Zeitgeist is emerging and some actors perform well in it. In this respect, France has experienced a restructuring of its political system, to the degree that the last presidential elections (2017) proved to be a turning point in the light of the struggle between En Marche! founder Emmanuel Macron and National Front's leader Marine Le Pen, who embodies a social frame that is distrusting of Liberalism and warns against post-materialist values, which the so-called installés people (Jaffré, 2017) tend 
to identify with. On behalf of a brand-new class linked to the contemporary 'economy of knowledge', such a category gathers cosmopolitan individuals belonging to urban areas who are embedded into the circuits of the services sector. On the contrary, scholars have observed that right-wing populism's consensus grows in direct proportion to the distance from such areas, like the core of biggest cities (Métropoles), and this since 2002 presidential elections, when former National Front's leader Jean-Marie Le Pen acceded to the runoff ballot for the first time (Ravenel et al., 2003). Thus, space and territory have become key factors for explaining new shapes of social and political fractures: to the extent that it expresses a territorial rootedness, the more recent crisis of Yellow Vests reveals on its own the cleavage between peripheral lower-middle classes and individuals with superior cultural capital, who benefited from the transition from industrial society. In this sense, different attitudes in terms of mobility, cultural openness and level of education represent crucial variables in clarifying such a new divide between centrality and marginality.

In this framework, where the opposition between xenophobia and multiculturalism became structural and reshape the political landscape, the effects of Globalization have exacerbated people's uncertainties and the sense of losing national sovereignty and economic well-being in the heart of many national societies (Appadurai, 2017). In this sense, the growth of National Front/Rally or the rise of Yellow Vests movement in France must be seen as symptomatic backlash (Norris and Inglehart, 2019) with respect to new global phenomena upsetting cultural and lifestyle dimensions, that have contributed to nourish the hantise du déclin (Giblin, 2017), an obsession about the decadence of French Grandeur.

\section{References}

Algan Y., Malgouyres C. e Senik C. (2020), 'Territoires, bien-être et politiques publiques', in Note du Conseil d'analyse économique n.55, January.

Appadurai A. (2017), Sicuri da morire. La violenza nell'epoca della globalizzazione. Meltemi, Rome.

Battaglia M. (2017), 'Le FN, premier parti des jeunes... qui votent. Les sondeurs et les sociologues s'accordent sur un point : la percée du Front national chez les jeunes est inédite,' in Le monde 12 avril.

Betz H. G. (1994), Radical right-wing populism in Western Europe. MacMillan, London.

Boyer P., Delemotte T., Gauthier G., Rollet V. and Schmutz B. (2019), 'Les déterminants de la mobilisation des "gilets jaunes', CREST n.6,.

Bornschier S. (2008), 'France - the model case of party system transformation', in Kriesi H., Grande E., Lachat R., Dolezal M., Bornschier S., and Frey T., (eds.) West European Politics in the Age of Globalization. Cambridge University Press, Cambridge, 77-104.

Bruneau I., Mischi J. and Renahy N. (2019), 'Les Gilets Jaunes en campagne - une ruralité politique, in AOC - Analyse Opinion Critique'- Cahier \#1, "Gilets Jaunes " : Hypotheses Sur un Mouvement - Vol 01.

Crépon S. (2012), La Nouvelle Extreme Droite. Enquête sur les jeunes militants du Front National L'Harmattan, Paris. 
Depraz S. (2019), 'La France contrainte des «gilets jaunes »', in AOC - Analyse Opinion Critique'- Cahier \#1, "Gilets Jaunes " : Hypotheses Sur un Mouvement - Vol 01.

Dézé A. (2016), Comprendre la Front National. Éditions Bréal, Lyon.

Donzelot J. (2019), 'La ville et le territoire. Ce qui a changé durant les cinquante dernières années', in Tous Urbains, Vol.26, n.2, 32-37.

Espagno D. and François S. (2015) 'Le Front National et les services publics. Un renouveau programmatique?' in Crépon S. (ed.), Les faux-semblants du Front national. Presses de Sciences Po, Paris, 207-224.

Fourquet J. (2017), Radiographie des votes ouvriers. Note de la Fondation Jean Jaurès, March.

Fourquet J. (2018), ‘À la droite de Dieu, Le réveil identitaire des catholiques', in Revue des sciences religieuses, 92/3, Cerf, Paris, 431-2.

Fourquet J. (2019), Anti-80 km/h: signe avant-coureur des "Gilets Jaunes". Note de la Fondation Jean Jaurès, February.

Giblin B. (2017), Le paradoxe français. Entre fierté nationale et hantise du déclin, Armand Colin,.

Gomant F. (2019), 'Le mouvement des « gilets jaunes » : une illustration criante de la peur du déclassement', in Après-demain 2019/2, n. 50, 23-25.

Gombin J. (2016), Le Front National, Eyrolles, Paris.

Goodhart D. (2019), Les deux clans. La nouvelle fracture mondiale, Les Arènes, Paris.

Gougou F. (2015), 'Les ouvriers et le vote Front National. Les logiques d'un réalignement électoral' , in Crépon S., Dézé A. and Mayer N. (eds), Les faux-semblants du Front national, Presses de Sciences Po, Paris.

Guilluy C. (2016), Le crépuscule de la France d'en haut. Flammarion, Paris.

Hawkins K.A, Carlin R.E, Littvay L. and Rovira Kaltwasser C. (ed.) (2018) The ideational approach to populism. Concept, theory and analysis. Routledge, London.

Huelin J.P. (2013), Où en est le vote ouvrier ? Note de la Fondation Jean Jaurès, n.151, January.

Ivaldi, G. (2015) 'Droites populistes en Europe : le régime proportionnel « favorable »?' in Revue Politique et Parlementaire, Colin, 2015, n. 1076

Jaffré J. (2017), 'Un second tour de présidentielle si différent du duel Chirac-Le Pen de 2002', in Perrineau P. (ed.), Le vote disruptif. Les élections présidentielle et législatives de 2017. Presses de Sciences Po, Paris,. 269-284.

Jenmana T. and Gethin A. (2017), 'Du mal-être au vote extrême', in Observatoire du Bien-être du CEPREMAP, 08, September.

Katz R. S. and Mair P (1995), 'Changing Models of Party Organization and Party Democracy: The Emergence of the Cartel Party', in Party Politics, 1,1, 5-28, 1995. 
Kriesi H., Grande E., Lachat R., Dolezal M., Bornschier S., and Frey T. (2008),

'Globalization and its impact on national spaces of competition'in Kriesi H., Grande E.,

Lachat R., Dolezal M., Bornschier S., and Frey T., (eds.) West European Politics in the Age of Globalization. Cambridge University Press, Cambridge.

Laclau E. (2008), La ragione populista. Laterza, Bari.

Le Bras H. and Todd E.(2013), Le mystère français. Seuil, Paris.

Le Bras H. (2019) 'La voiture, les « gilets jaunes » et le Rassemblement national' in Études, avril, 4, 31-44.

Lévy J. (2013) Réinventer la France. Trente cartes pour une nouvelle géographie. Fayard, Paris, 2013

Lévy J. and Lussault M. (eds.) (2019), Dictionnaire de la Géographie et de l'espace des sociétés, Belin, Paris.

Lussault M. (2012), Trans-spatialités urbaines, in "Hérmes, La Revue" Issue 2, pp. 67-74.

Lussault M. (2019), 'Des ronds-points et de la condition périurbaine' in AOC - Analyse Opinion Critique - Cahier \#1, "Gilets Jaunes " : Hypotheses Sur un Mouvement - Vol. 01.

Mair P.(2009) Ruling The Void: The Hollowing Of Western Democracy. Verso, London.

Marlière P. (2019) France's Yellow Vests: the momentum is gone. Open Democracy 2019.

Mazeau G. (2019) 'Les Gilets Jaunes et la Révolution française: quand le peuple reprend 1'histoire', in AOC - Analyse Opinion Critique - Cahier \#1, "Gilets Jaunes " : Hypotheses Sur un Mouvement - Vol. 01.

Michelat G. and Simon M. (2012), Le vote des ouvriers, de l'alignement à gauche à une «droitisation»? Note du CEVIPOF, Paris, January23.

Mounk Y. (2018) Le peuple contre la démocratie. Editions de l'Observatoire, Paris, 2018.

Mudde C. (Ed.), (2017) On extremism and democracy in Europe. Routledge, London.

Müller J.W. (2016), What Is Populism?. University of Pennsylvania Press.

Norris P. and Inglehart R. (2019), Cultural Backlash. Trump, Brexit and Authoritarian Populism. Cambridge University Press, Cambridge.

Orfali B. (2012) L'Adhésion à l'extrême droite, L'Harmattan, « Logiques Sociales », Paris.

Ostiguy P. (2017), 'Populism: A Socio-Cultural Approach,' in Kaltwasser C. R., Taggart P., Espejo P. O. and Ostiguy P. (eds.),The Oxford Handbook of Populism, Oxford University Press, Oxford.

Panizza F. (ed.) (2005), Populism and the mirror of democracy. Verso, London.

Paugam S. (2019), 'Face au mépris social, la revanche des invisibles', in Cahiers AOC, La Découverte, Paris.

Perona M. and Péron M. (2018), Bonheur rural, malheur urbain ? Note de l'Observatoire du bien-être, n.7, November. 
Perona M. (2019) La France malheureuse. Note de l'Observatoire du bien-être, n.1, February. Perrineau P. (2014), La France au front. Fayard, Paris.

Ravenel L., Buléon P. and Fourquet J. (2003),'Vote et gradient d'urbanité : les nouveaux territoires des élections présidentielles de 2002', in Espace, populations, sociétés, 2003-3, Populations, élections, territoires, pp.469-482.

Reynard R. e Vallès V. (2019) Les emplois se concentrent très progressivement sur le territoire, les déplacements domicile-travail augmentent, Note INSEE, n.1771, September.

Reynié D. (2011),'Le tournant ethno-socialiste du Front national', in Études, Vol. 415, 463 472

Reynié D. (2013) Les nouveaux populismes, Flammarion, Paris,.

Rooduijn M., de Lange S. and van der Brug W. (2012), 'A populist Zeitgeist? Programmatic contagion by populist parties in Western Europe', in Party Politics, Volume: 20 4, 563-575

Sauger N., Brouard S. and Grossmann E. (2007) Les Français contre l'Europe? Le sens du référendum du 29 mai 2005. Presses de Sciences Po, Paris.

Slama A. G. (2016), 'La droite, jusqu'où ?', in Le Débat, 191, 4, 121-133 .

Taguieff P.A. (1984), 'La rhétorique du national-populisme : Les règles élémentaires de la propagande xénophobe' , in Mots. Les langages du politique, 9, 1, 113-139

Taguieff P.A. (2012), Le nouveau national-populisme. Editions du CNRS.

Veltz P. (2019), La France des territoires, défis et promesses. L'Aube, La Tour-d'Aigues.

Viard J. (2011), Nouveau portrait de la France. La société des modes de vie. Editions de l'Aube, Paris.

Wieviorka M. (2013) ,'Social Conflict', in Current Sociology, 61,5-6, 696-713. 
(c) $(\mathrm{C}$

This article is distributed under the terms of the Creative Commons Attribution 4.0 License (https://creativecommons. org/licenses/by/4.0/) which permits any use, reproduction and distribution of the work without further permission provided the original work is attributed as specified on the WCSA Journal by World Complexity Science Academy (https://www.wcsaglobal.org/ethics-policy/). 